\title{
Heterotrophic dinoflagellates with symbiotic cyanobacteria and nitrogen limitation in the Gulf of Aqaba
}

\author{
N. Gordon ${ }^{1}$, D. L. Angel ${ }^{1}$, A. Neori ${ }^{1, *}$, N. Kress ${ }^{2}$, B. Kimor ${ }^{3}$ \\ ${ }^{1}$ National Center for Mariculture, Israel Oceanographic and Limnological Research Ltd, POB 1212, Eilat 88112, Israel \\ ${ }^{2}$ National Institute of Oceanography, Israel Oceanographic and Limnological Research Ltd, POB 8030, Haifa 31080, Israel \\ ${ }^{3}$ Technion - Israel Institute of Technology, Faculty of Agricultural Engineering, Haifa 32000, Israel
}

\begin{abstract}
Many symbiotic associations characteristic of tropical and subtropical oceanic waters were observed near shore during a long-term study of the microbiota in the northern part of the Gulf of Aqaba, Red Sea. Among such associations were the heterotrophic dinophysoid genera Ornithocercus, Histioneis and Citharistes with cyanobacterial symbionts. The detection of these heterotroph-autotroph consortia repeatedly coincided with extended nitrogen limitation in the fall season. Populations of free-living cyanobacteria, with known $\mathrm{N}$ fixation capability, such as the unicellular Synechococcus/ Synechocystis spp. and colonial forms, e.g. Trichodesmium spp., also peaked at the same time. We propose that heterotrophic dinoflagellate hosts may provide the cyanobacterial symbionts with the anaerobic microenvironment necessary for efficient $\mathrm{N}$ fixation. Thus, these self-supporting consortia increase in numbers during the long period of stratification and nitrogen limitation in the oligotrophic subtropical waters of the Gulf of Aqaba.
\end{abstract}

KEY WORDS: Dinophysiaceae · Heterotrophy - Cyanobacteria · Symbiosis · Nitrogen limitation Nutrients · Oligotrophic Plankton S Subtropical - Stratification

\section{INTRODUCTION}

The heterotrophic dinophysoid genera Omithocercus, Histioneis and Citharistes are common mostly in deep oceanic waters of tropical and subtropical seas (Gaines \& Elbrachter 1987, Taylor 1987). They are devoid of photosynthetic pigments, have no evidence of phagotrophic inclusions in their cytoplasm (Gaines \& Elbrachter 1987, Taylor 1987) and are thought to feed osmotrophically (Droop 1974). These dinoflagellates often host clusters of cyanobacteria, rod-ovoid or spherical shaped, corresponding to Synechococcus carcerarius Norris and Synechocystis consortia Norris respectively. The cyanobacterial symbionts, also known as phaeosomes (Norris 1967, Taylor 1982, 1990), are located between the upper and lower lists of the horizontal groove of the cells, as in Ornithocercus and Histioneis (congeneric according to Balech 1971) or within special chambers inside the cells, as in Citharistes.

- Addressee for correspondence
The dinoflagellate-phaeosome consortia were recorded in the plankton of the northern part of the Gulf of Aqaba at Stn A (depth $600 \mathrm{~m}$ ) during a long-term study of the microbiota of this marine environment (Fig. 1, inset). Their occurrence, so close to shore, in spite of their oceanic preferences, may be related to the particular configuration of the Gulf, a very narrow shelf and steep submarine slopes harboring very deep water masses. The peculiar geomorphological features of the Gulf may thus favor co-existence of what are typically considered oceanic and neritic species (Smayda 1958). The oligotrophic nature of the Gulf, especially in its northern part (Klinker et al. 1978, Levanon-Spanier et al. 1979, Reiss \& Hottinger 1984 and references therein, Weickert 1987), constitutes an additional factor in the occurrence of oceanic symbiotic associations among the microplankton in general and of dinoflagellate-cyanobacteria consortia in particular (Guillard \& Kilham 1977, Hallegraeff \& Jeffrey 1984, Kimor et al. 1992). The recurrent appearance of heterotrophic dinoflagellates harboring symbionts primarily during the autumn season, following many months of thermal stratification, prompted this study. 


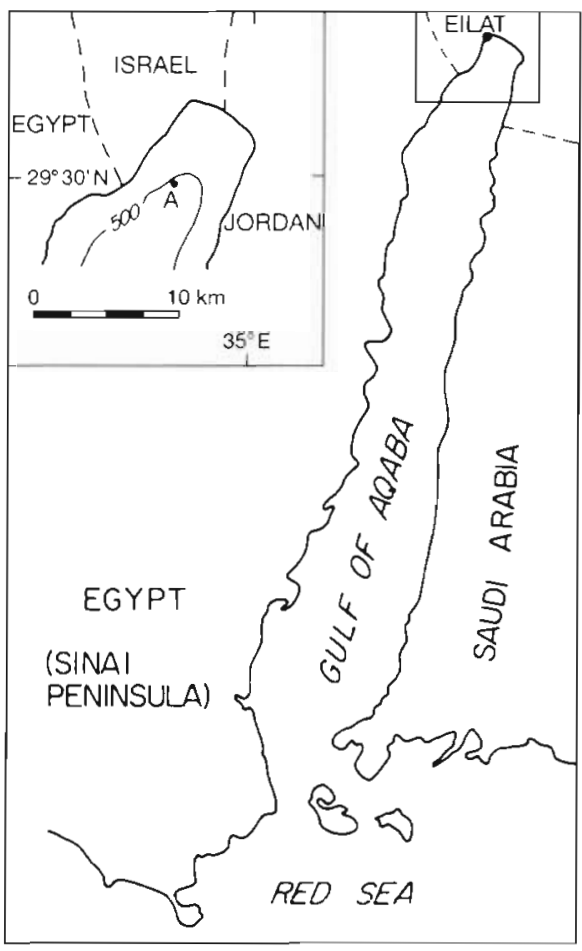

Fig. 1. Location of Stn A (see inset) at the northern end of the Gulf of Aqaba, Red Sea

\section{MATERIALS AND METHODS}

Water samples were collected 4 times $\mathrm{yr}^{-1}$ using Niskin bottles from a series of depths $(0-5,20,60,80$ $100,120,150,200,300,400,500,600 \mathrm{~m})$ at a reference station (Stn A) located 2 miles from shore where the water depth is 550 to $600 \mathrm{~m}$ (Fig. 1).

Water samples (300 to $400 \mathrm{ml}$ ) were concentrated on $25 \mathrm{~mm}$ polycarbonate filters using the filter-transferfreeze (FTF) method (Hewes \& Holm-Hansen 1983) and cells were measured, counted and photographed by epifluorescence and transmitted light microscopy. The orange or yellow fluorescence characteristic of phycoerythrin-rich cyanobacterial symbionts contrasted sharply with the green fluorescence of the heterotrophic dinophysoid hosts when using this technique. The cell recovery efficiency of the FTF method was shown to be high (Hewes et al. 1984). In our own hands (calibrated by comparing live and FTF counts of cultures of the naked dinoflagellate, Oxyrrhis sp.) recovery ranged between 85 and $98 \%$ (Gordon unpubl.). The detection limit of our cell counts allowed us to detect

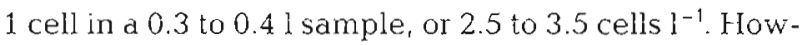
ever, if we consider the total volume filtered per cruise (at least 2 to $3 \mathrm{l}$ from 7 samples of $300 \mathrm{ml}$ ), the detection limit per cruise drops to about 0.5 cells $1^{-1}$.
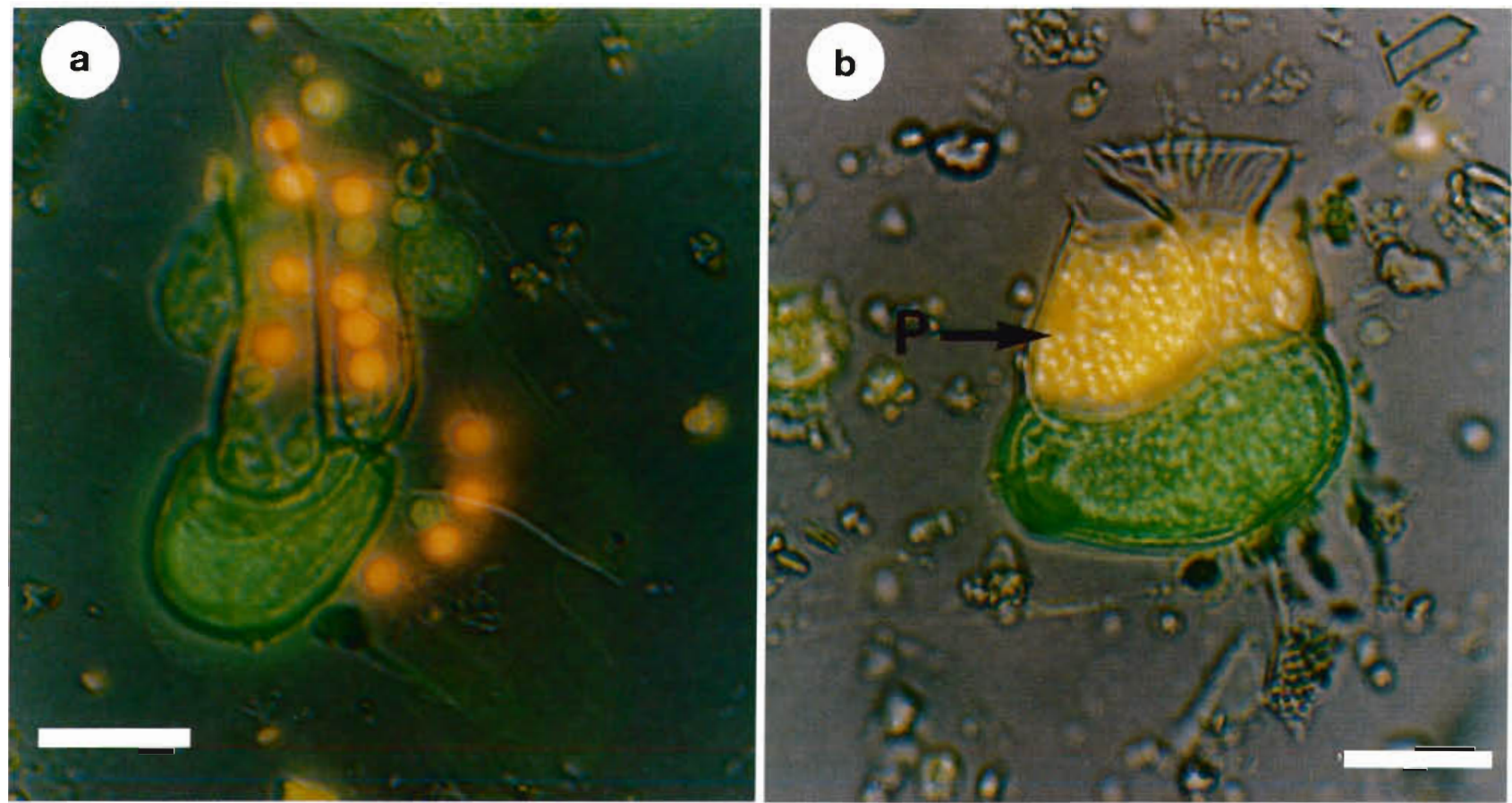

Fig. 2. (a) Histioneis milneri Murray \& Whitting, (b) H. carinata Kof., (c) Citharistes regius, (d) H. biremis Stein, (e) Ornithocercus quadratus, (f) $O$. splendidus. All of these heterotrophic dinoflagellates are associated with phaeosomes (cyanobacterial symbionts). The phaeosomes (P) are unicellular cyanobacteria of the Synechococcus or Synechocystis types, characterized by yellow/orange autofluorescence [see arrow in (b)], and they are generally considerably larger than the free-living Synechococcus/Synechocystis spp. in these waters. Phaeosomes are located either between the cingular lists of the horizontal groove, or within specialized chambers inside the cell. Scale bars $=20 \mu \mathrm{m}$ 
Biomass of Synechococcus/Synechocystis spp. was determined by multiplying mean cell counts by mean cell volume (determined by microscope measurements) and converting the biovolume to carbon biomass using the Strathman (1967) conversion factor (250 fg $\mathrm{C} \mu \mathrm{m}^{-3}$ ).

Nitrate concentration in the seawater samples was determined by a Technicon II autoanalyzer (Krom et al. 1991)
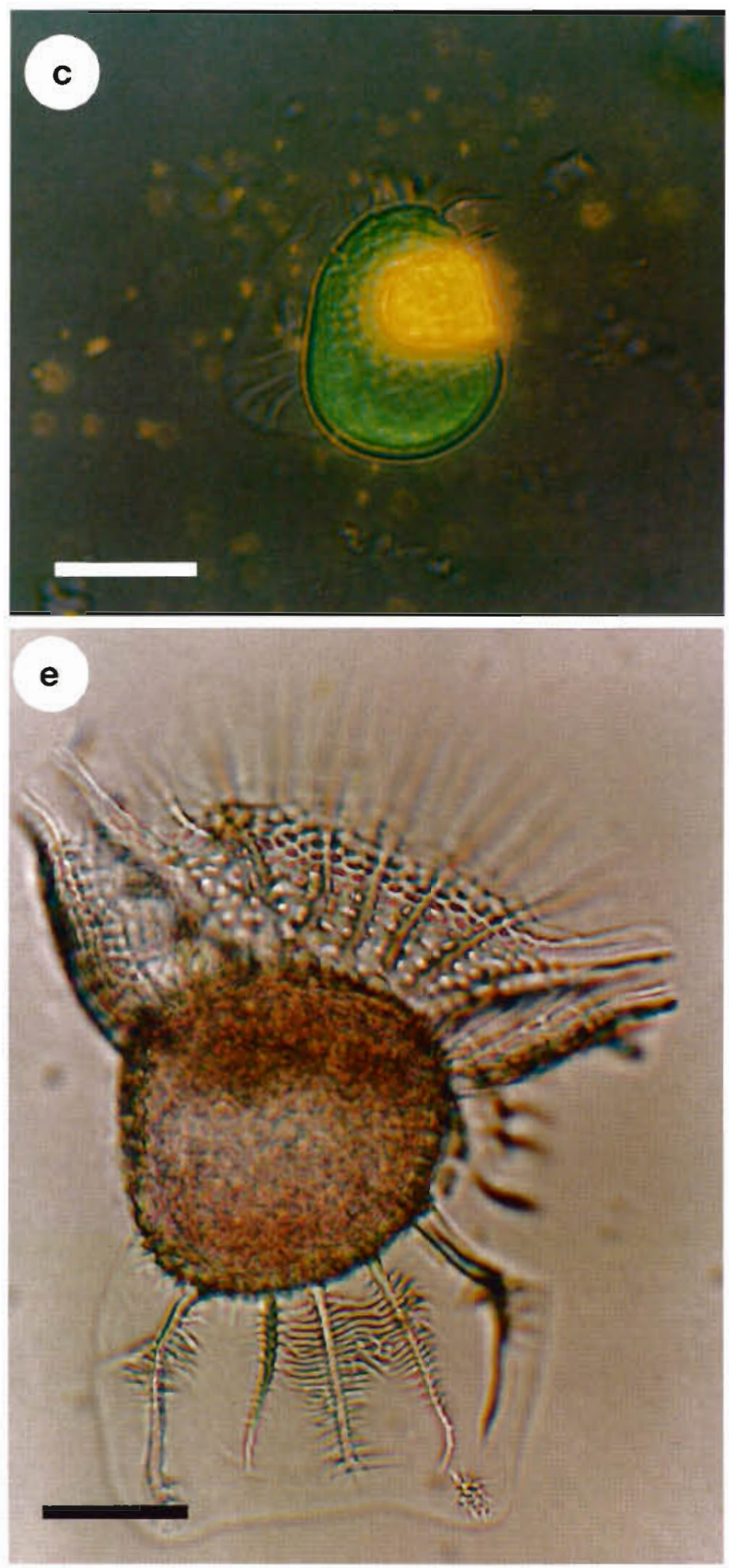

\section{RESULTS AND DISCUSSION}

An analysis of the plankton samples collected over a period of nearly $5 \mathrm{yr}$ at Stn $\mathrm{A}$ in the Gulf of Aqaba indicated a recurring appearance of dinophysoidcyanobacteria consortia almost exclusively during the autumn (Table 1, Fig. 2). A total of 25 positive observations of such consortia were made in the fall months of October and November (1989, 1990, 1991 and 1992),
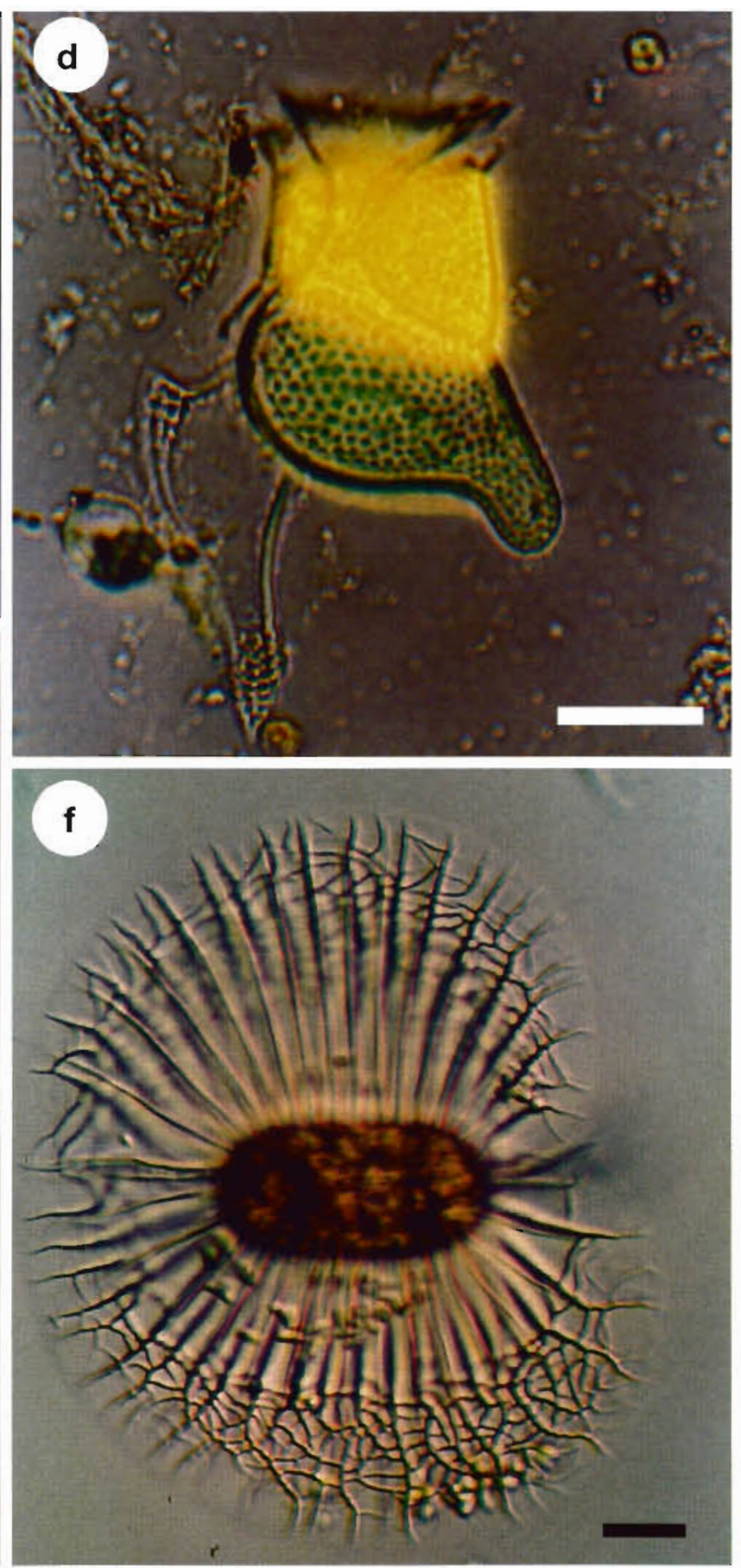
Table 1. Summary of the seasonal appearance and depth distribution of dinophysoids with unicellular cyanobacterial symbionts collected at Stn A in the northern Gulf of Aqaba, Red Sea. Dinophysoid abundance ranged from 3 to 6 cells $1^{-1}$ Species codes are as follows - a: Histioneis milneri Murray \& Whitting; b: H. carinata Kof.; c: Citharistes regius Stein; d: H. biremis Stein; e: Ornithocercus quadratus Schutt; $\mathrm{f}$ O $O$. splendidus Schutt; g: $H$. para Murray \& Whitting; h: H. dubia Bohmi i: H. minuscula Rampi ${ }_{i}$ : Histioneis sp.i k: Histioneis sp.; l: H. schillen Bohm

\begin{tabular}{|c|c|c|c|c|c|c|c|}
\hline \multirow{2}{*}{ Date } & \multicolumn{7}{|c|}{ Depth (m) } \\
\hline & $0-20$ & $20-40$ & $40-60$ & $60-80$ & $80-100$ & $100-120$ & $120-140$ \\
\hline \multicolumn{8}{|l|}{ Jul 1988} \\
\hline \multicolumn{8}{|l|}{ Sep 1988} \\
\hline Oct 1989 & j & & & & j & & \\
\hline \multicolumn{8}{|l|}{ Dec 1989} \\
\hline Mar 1990 & k & & & & $\mathrm{k}$ & & \\
\hline \multicolumn{8}{|l|}{ May 1990} \\
\hline \multicolumn{8}{|l|}{ Jul 1990} \\
\hline Oct 1990 & & & & & $\mathrm{k}$ & k & \\
\hline Nov 1991 & g & k & & c & $c, h, l$ & $\mathrm{c}, \mathrm{i}$ & c \\
\hline Mar 1992 & & & & a & & & \\
\hline \multicolumn{8}{|l|}{ Jul 1992} \\
\hline Oct 1992 & $b, d, e, f, g, h, k$ & $g, h$ & & $\mathrm{~h}$ & k & & k \\
\hline
\end{tabular}

tion. The latter is already strong in summer (Fig. 3; Levanon-Spanier et al. 1979). We thus feel the development of the populations discussed is more likely related to nutrients and stratification than to any other of the major environmental factors.

We propose that the symbiotic consortia discussed here begin to grow during the late spring. By July, nitrogen limitation is already severe, but the dinophysoid populations are still too small to reach our detection limit of 0.5 cells $l^{-1}$. Their numbers peak in the fall, following the extended period of both nitrogen limitation (which favors efficient $N$ fixers) and stratification, which allows slow growers such as dinoflagellates and $\mathrm{N}$ fixers to build up their populations.

The proposed function of the heterotrophic dinophysoid host in the dinoflagellate-cyanobacteria consortia reported while only 3 observations were recorded during other seasons, 2 of them during March 1990 and the third during March 1992.

Extreme nutrient limitation is an outstanding and well-documented feature of the fall season in the waters of the Gulf of Aqaba (Levanon-Spanier et al. 1979, Reiss \& Hottinger 1984, Lazar \& Erez 1991). This limitation, especially of nitrate, results from the extended depletion of nutrients from the euphotic zone from spring to fall. The nutrients disappear during a long period of thermal stratification, which begins in April-May of each year and lasts until the onset of winter vertical mixing, approximately in December. Fig. 3 shows the effect of a typical full annual cycle of destratification and stratification on the depth-profiles of nitrate and of free-living cyanobacteria. In November 1991, nitrate was already depleted in the top $150 \mathrm{~m}$ of the water. In March 1992, nitrate was replenished in the top layer as a result of the winter mixing. The profiles from July and October 1992 show the slow deepening of the nitrate-stripped layer. This process coincided with the emergence of detectable populations of the dinophysoid symbiotic associations (Fig. 2, Table 1).

Different factors can influence microplanktonic population structure. The major factors are light, temperature, physical characteristics and nutrients. In the Gulf of Aqaba, temperature varies only from $21^{\circ} \mathrm{C}$ in winter to $26^{\circ} \mathrm{C}$ in summer (Reiss \& Hottinger 1984). Both light and temperature conditions are quite similar in October-November and in March-April. The only major factors which are quite different between fall and spring are the nutrients and the thermal stratifica-

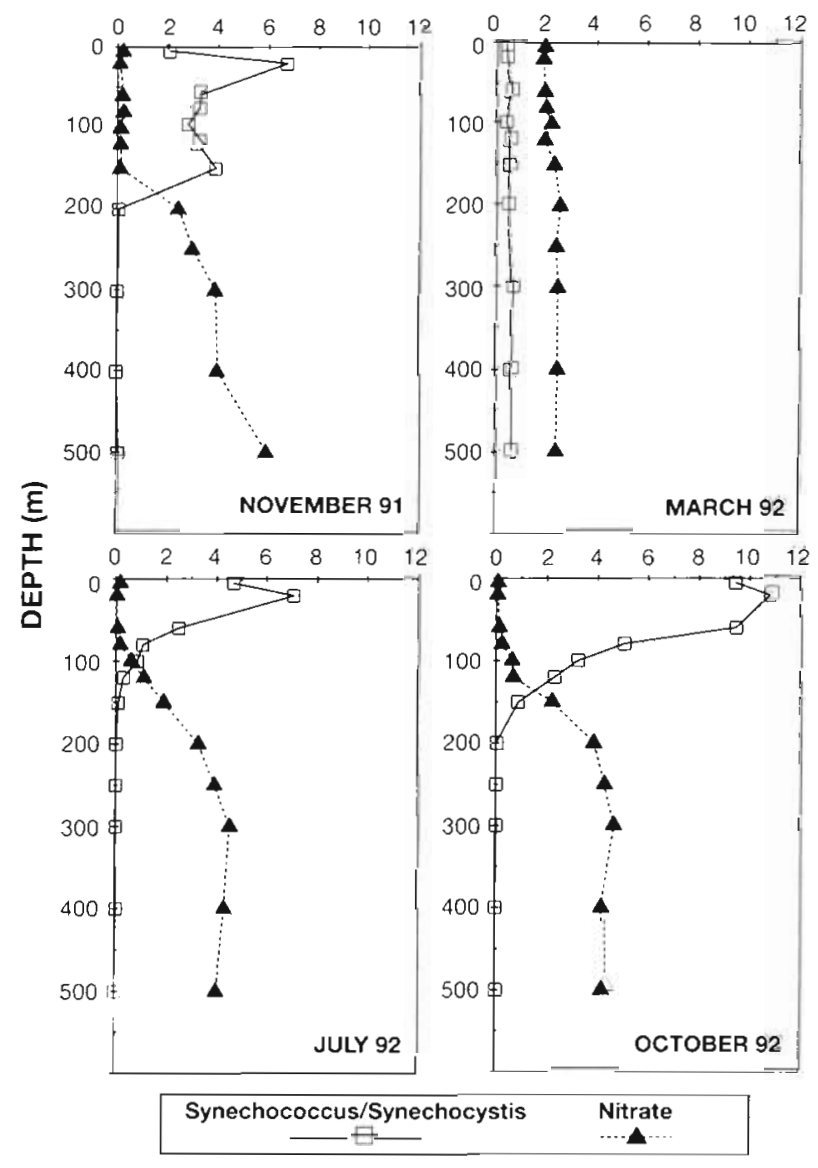

Fig. 3. Seasonal vertical profiles of nitrate $\left(\mathrm{NO}_{3}^{-}\right)$concentration $(\mu \mathrm{M})$ and free-living Synechococcus /Synechocystis spp. biomass ( $\mu \mathrm{g} \mathrm{C}^{-1}$ ) at $\mathrm{Stn} A, 1991-1992$ 
here (Fig. 2) is provision of the anaerobic microenvironment necessary for $\mathrm{N}$ fixation by the cyanobacterial symbionts in oligotrophic waters. The activity of the nitrogen-fixing enzyme nitrogenase requires low oxygen tension for its synthesis and activity (Postgate 1982). However, low oxygen conditions are scarce in oligotrophic waters (Paerl et al. 1987). Cyanobacteria have evolved a variety of strategies to fix nitrogen in oxygenated waters, such as heterocysts (Wolk 1982). Colonial non-heterocystous cyanobacteria form regions of low oxygen tension at the center of their colonies to enable nitrogenase activity (Kallas et al. 1983, Paerl et al. 1989). Even non-colonial, non-heterocystous chroococcoid cyanobacteria are able to fix nitrogen, albeit less efficiently (cells alternate between aerobic photosynthesis and anaerobic $\mathrm{N}$ fixation metabolisms) in highly oxygenated, oligotrophic waters (Kallas et al. 1983, Leon et al. 1986, Mitsui et al. 1986, Spiller \& Shanmugam 1987, Paulsen et al. 1991).

There are several lines of evidence supporting our proposition:

(1) Cyanobacteria have been shown to exude a large proportion of their fixed carbon (Raven 1987). By supplying the host with respirable organic exudates, the cyanobacterial symbionts are likely to accelerate oxygen consumption in their immediate proximity, and thus to activate the nitrogenase for a longer time than their free-living peers.

(2) The abundance of free-living Synechococcus/ Synechocystis sp., which constitutes a major fraction of the total autotrophic biomass in the Gulf water yearround (Neori et al. unpubl.), increased in the surface waters in correlation with nitrate limitation, and usually peaked in the autumn (Fig. 3). Nitrate and Synechococcus/Synechocystis sp. were evenly distributed throughout the water column only during the winter mixing (Fig. 3).

(3) Populations of the diazotrophic filamentous cyanobacterium Trichodesmium thiebautii and the colonial chroococcoid cyanobacterium Aphanocapsa littoralis also occurred almost exclusively in the autumn (Gordon unpubl.). They were not detected during the winter mixing, instead, seasonal peaks were observed in populations of large autotrophic phytoplankton, mainly diatoms and dinoflagellates, as well as the heterotrophic tintinnids (which occupy the same ecological niche as the symbiotic dinophysoids) (Kimor \& Golandsky 1977. Levanon-Spanier et al. 1979, Kimor \& Golandsky-Baras 1981, Gordon unpubl.).

In conclusion, we feel there is evidence that populations of some cyanobacteria increase during the $\mathrm{N}$ limitation months, conceivably due to their $\mathrm{N}$ fixing capability. There is also evidence that larger $\mathrm{N}$ fixing cyanobacteria may have some advantages over freeliving single cells in creating sites of low oxygen ten- sion in highly oligotrophic waters. Our hypothesis is that in the consortia discussed here, the heterotrophic dinoflagellate hosts provide their unicellular cyanobacterial symbionts with similar advantages. This premise has yet to be examined experimentally.

If our hypothesis is correct, one could still question the ecological relevance of organisms with such low abundances as the discussed dinophysoid-cyanobacterial consortia in the Gulf waters. However, even nonabundant microplankters may substantially contribute to nutrient and plankton dynamics in oligotrophic waters (Villareal \& Carpenter 1989, Goldman 1993). If the symbiosis makes $\mathrm{N}$ fixation of the symbionts more efficient, the consortia may contribute to the nitrogen and productivity dynamics of the euphotic zone in the Gulf more than their numbers suggest. Additionally, their population increase serves as an easily distinguishable and useful bioindicator of extreme and extended oligotrophic conditions, as occur in the Gulf of Aqaba in the fall of each year. It will be interesting to examine this relationship in other regions of the world oceans.

Acknowledgements. The authors express their thanks and appreciation to the organizers of DINO 5 (Fifth International Conference on Modern and Fossil Dinoflagellates, held in Zeist, Netherlands in April 1993) for the opportunity to present the topic of this paper as a subject for discussion. This study was partially supported by the Israeli Ministry of Energy and Infrastructure, project no. 91-06-065, by funding from The National Center for Mariculture and the Buki Fund. We thank Dr J. Beers for his useful comments and Dr $M$. Elbrachter for his assistance in assigning species names to the Histioneis in our samples. We would like to acknowledge the Steinitz Marine Laboratory, especially Dr Amatzia Genin, and the crews of the 'Sunboat', 'Jadran' and 'Manta Ray' for their assistance in collecting the water samples at Stn A.

\section{LITERATURE CITED}

Balech, E. (1971). Microplancton del Atlantico ecuatorial oeste (Equalant 1). Servicio de Hidrografia Naval, Argentina, Buenos Aires, H. 654

Droop, M. R. (1974). Heterotrophy of carbon. In: Stewart, W. D. (ed.) Algal physiology and biochemistry. Univ. of Calif. Press, Berkeley, p. 530-599

Gaines, G., Elbrachter, M. (1987). Heterotrophic nutrition. In: Taylor, F. J. R. (ed.) The biology of dinoflagellates. Blackwell Scientific Publ., Oxford, p. 229-267

Goldman, J. C. (1993). Potential role of large oceanic diatoms in new primary production. Deep Sea Res. 40: 159-168

Guillard, R. L., Kilham, P. (1977). The ecology of marine planktonic diatoms. In: Werner, D. (ed.) The biology of diatoms. Univ. of Calif. Press, Berkeley, p. 372-409

Hallegraeff, G. M., Jeffrey, S. W. (1984). Tropical phytoplankton species and pigments of continental shelf waters of North and North-West Australia. Mar. Ecol. Prog. Ser. 20: $59-74$

Hewes, C. D., Holm-Hansen, O. (1983). A method for recovering nanoplankton from filters for identification by micro- 
scope. The filter-transfer-freeze (FTF) technique. Limnol. Oceanogr. 28: 389-394

Hewes, C. D., Reid, F. M. H., Holm-Hansen, O. (1984). The quantitative analysis of nanoplankton: a study of methods. J. Plankton Res. 6: 601-613

Kallas, T., Rippka, R., Coursin, T., Rebiere, M. C., Tandeau de Marsac, N., Cohen-Bazire, G. (1983). Aerobic nitrogen fixation by nonheterocystous cyanobacteria. In: Papageorgiou, G. C., Packer, L. (eds.) Photosynthetic prokaryotes: cell differentiation and function. Elsevier, New York, p. 281-302

Kimor, B., Golandsky, B. (1977). Microplankton of the Gulf of Elat. Aspects of seasonal and bathymetric distribution. Mar. Biol. 42: 55-67

Kimor, B., Golandsky-Baras, B. (1981). Distribution and ecology of the tintinnids in the Gulf of Elat (Aqaba), Red Sea. J. Plankton Res. 3: 445-459

Kimor, B., Gordon, N., Neori, A. (1992). Symbiotic associations among the microplankton in oligotrophic marine environments with special reference to the Gulf of Aqaba, Red Sea. J. Plankton Res. 14: 1217-1231

Klinker, J., Reiss, Z., Krapach, C., Levanon, I., Harpaz, H., Shapiro, Y. (1978). Nutrients and biomass distribution in the Gulf of Aqaba (Elat), Red Sea. Mar. Biol. 45: 53-64

Krom, M. D., Kress, N., Brenner, S., Gordon, L. I. (1991). Phosphorus limitation of primary productivity in the eastern Mediterranean Sea. Limnol. Oceanogr. 36: 424-432

Lazar, B., Erez, J. (1991). Estimation of prmary production in the Gulf of Elat, Red Sea from water column chemistry. In: Proc. 12th Conf. Interuniversity Inst. Feb. 26-Mar. 1, 1991 H. Steinitz Marine Biology Laboratory, Elat, Israel, p. $54-56$

Leon, C., Kumazawa, S., Mitsui, A. (1986). Cyclic appearance of aerobic nitrogenase activity during synchronous growth of unicellular cyanobacteria. Curr. Microbiol. 13: $149-153$

Levanon-Spanier, I., Padan, E., Reiss, Z. (1979). Primary production in a desert-enclosed sea - the Gulf of Elat (Aqaba), Red Sea. Deep Sea Res. 26/6A: 673-685

Mitsui, A., Kumazawa, A., Takahashi, A., Ikemoto, H., Cao, S., Anai, T. (1986). Strategy by which nitrogen-fixing unicellular cyanobacteria grow photoautotrophically. Nature 323: 720-722

Norris, R. E. (1967). Algal consortia in marine plankton. In: Krishnamurti, V. (ed.) In: Proceedings fo the seminar on sea, salt and plants, 1965. Central Salt and Marine Chemistry Institute, Bhavnagar, India, p. 178-189

Paerl, H. W., Crocker, K. M., Prufert, L. E. (1987). Limitation of

This article was submitted to the editor
$\mathrm{N}_{2}$ fixation in coastal marine waters: relative importance of molybdenum, iron, phosphorus, and organic matter availability. Limol. Oceanogr. 32: 525-536

Paerl, H. W., Bebout, B. M., Prufert, L. E. (1989). Bacterial associations with marine Oscillatoria sp. (Trichodesmium sp.) populations: ecophysiological implications. J. Phycol. 25: $773-784$

Paulsen, D. M., Paerl, H. W., Bishop, P. E. (1991). Evidence that molybdenum-dependent nitrogen fixation is not limited by high sulfate concentrations in marine environments. Limnol. Oceanogr. 36: 1325-1334

Postgate, J. R. (1982). The fundamentals of nitrogen fixation. Cambridge University Press, Cambridge

Raven, J. A. (1987). Physiological consequences of extremely small size for autotrophic organisms in the sea. In: Platt, T., Li, W. K. W. (eds.) Photosynthetic picoplankton. Can. Bull. Fish. Aquat. Sci. 214

Reiss, Z., Hottinger, L. (1984). The Gulf of Aqaba. Ecological micropalaeontology. Ecological Studies, Vol. 50. SpringerVerlag, Berlin

Smayda, T S. (1958). Biogeographical studies of marine phytoplankton. Oikos 9(II): 158-191

Spiller, H., Shanmugam, K. T (1987). Physiological conditions for nitrogen fixation in a unicellular marine cyanobacterium, Synechococcus sp. strain SF1. J. Bacteriol. 169: $5379-5384$

Strathman, R. R. (1967). Estimating the organic carbon content of phytoplankton from cell volume or plasma volume. Limnol. Oceanogr. 12: 411-418

Taylor, F. J. R. (1982). Symbioses in marine microplankton Annls Inst. océanogr., Paris 58: 61-90

Taylor, F. J. R. (1987). Ecology of dinoflagellates: A. General and marine ecosystems. In: Taylor, F. J. R. (ed.) The biology of dinoflagellates. Blackwell Scientific Publ. Oxford, p. 399-501

Taylor, F. J. R. (1990). Symbiosis in marine protozoa. In Capriulo, G. M. (ed.) Ecology of marine protozoa. Oxford Univ. Press, p. 323-340

Villareal, T A., Carpenter, E. J. (1989). Nitrogen fixation suspension characteristics and chemical composition of Rhizosolenia mats in the central North Pacific gyre. Biol. Oceanogr. 6: 327-345

Weickert, H. (1987). Plankton and the pelagic environment In: Edwards, A. J., Head, S. M. (eds.) Key environments, the Red Sea. Pergamon Press, New York, p. 90-111

Wolk, C. P. (1982). Heterocysts. In: Carr, N. G., Whitton, B. A (eds.) The biology of cyanobacteria. Blackwell Scientific Publ., Oxford, p. 359-386

Manuscript first received: July 7, 1993

Revised version accepted: January 31, 1994 